Digitalizacja archiwalnych numerów czasopisma naukowego Analecta Cracoviensia 1-24 (1969-1992) i ich publikacja w otwartym dostępie - zadanie finansowane w ramach umowy 672/P-DUN/2017 ze środków Ministra Nauki i Szkolnictwa Wyższego przeznaczonych na działalność upowszechniającą naukę

\title{
APOLOGIA W EPOCE DIALOGU Aktualne zadania teologii fundamentalnej
}

W ramach niniejszego wykładu ${ }^{1}$ chcemy się przyjrzeć pewnemu dylematowi, pewnemu napięciu, pewnemu nawet poczuciu sprzeczności, które może się rodzić stąd, że jedna z ważnych dyscyplin teologicznych, jaką jest teologia fundamentalna, uprawiana jest w ostatnich dziesięcioleciach w odmiennym kontekście kościelnym niż w wiekach, w których się wykrystalizowała. Dyscyplina ta mianowicie, zrodzona $w$ znacznej mierze $w$ ogniu polemik $\mathrm{z}$ trzema kategoriami ludzi jawiących się w przeszłości Kościołowi w zasadniczo negatywnym świetle jako oporni wobec światła Ewangelii (perfidi) poganie, Żydzi i heretycy (do których dołączyli jeszcze w poprzednim stuleciu gorsi od wszystkich poprzednich „,bezwyznaniowcy” i ,ateusze”), znalazła się, zwłaszcza od II soboru watykańskiego w sytuacji, w której Kościół spojrzał na całe ludzkie uniwersum jako na „rodzinę”2, gdzie wszyscy w jakiejś mierze przynależą lub są „przyporządkowani" (ordinantur ad) Ludowi Bożemu ${ }^{3}$ jako bracia w Chrystusie, jako członkowie „ludu dzięki wybraniu szczególnie umiłowanego ze względu na $\mathrm{Oj}$ ców"4 , jako wyznawcy bądź poszukujący Boga, jako ludzie dobrej woli. Zasadnicza postawa Kościoła wobec tak pojętej „,rodziny ludzkiej” została określona jako postawa dialogu.

$\mathrm{Na}$ ogół tę nową perspektywę przyjęto w Kościele z ulgą, jako wydobycie na jaw istotnych konsekwencji Ewangelii dotąd w praktyce nie dość uwzględnionych. Chrześcijaństwo jest wiarą w Miłość: wiarą w miłość Boga, który w Chrystusie pojednał świat ze sobą, nam przekazując misję jednania (por. 2 Kor 5,18-19) i wszelkie bariery stawiane tej misji musi odczuwać jako obce swej najgłębszej istocie skrępowanie. Zakłopotanie mogli przeżywać wszakże

${ }^{1}$ Poniższy tekst został przygotowany jako wykład na kolokwium habilitacyjne na Wydziale Teologicznym Papieskiej Akademii Teologicznej w Krakowie.

2 "Mundum igitur hominum prae oculis [Concilium] habet seu universam familiam humanam" (Gaudium et spes 2, w: Sobór Watykański II. Konstytucje, dekrety, deklaracje. Tekst tacińsko-polski, Poznań 1967, s. 830).

${ }^{3}$ Por. Lumen gentium $13-16$ (tamże, s. $168-173$ ).

${ }^{4}$ "[...] populus secundum electionem carissimus propter patres" (Lumen gentium 16, tamże s. $172-173)$. 
(i - sądząc po kryzysie tożsamości, jaki w latach posoborowych wstrząsnął teologią fundamentalną - faktycznie zapewne przeżywali) wykładowcy i badacze dziedziny określanej jeszcze wówczas często jako „apologetyka”: nauka o systematycznej i skutecznej apologii prawdziwej religii. Ze względu na teoretyczne przygotowanie stawali się oni zresztą nierzadko pionierami nawiązywanych przez Kościół dialogów ekumenicznych czy międzyreligijnych. Czy ta nowa sytuacja nie zmuszała do zaparcia się własnej postawy? Czy nie wymagała ona wyrzeczenia się samej koncepcji apologii własnej wiary? Czy takie wyrzeczenie jest — i w jakiej mierze - możliwe?

Wydaje się, że dziś można już na te wszystkie pytania spojrzeć spokojnie z pewnego dystansu, przyglądając się tekstom podstawowych dokumentów Kościoła, które zmieniły orientację podejścia Kościoła do świata; przyjrzeć się im z perspektywy bogatego doświadczenia dialogu Kościoła ze światem oraz odnalezienia na nowo swej tożsamości przez teologię fundamentalną.

W niniejszym wykładzie będziemy więc chcieli podkreślić naprzód, że od samych początków Kościoła poświadczona jest świadomość potrzeby obrony, apologii własnych przekonań religijnych. Apologie stanowią jedną z pierwszych form, w których wyraziła się myśl chrześcijańska. Przyjrzymy się następnie, jak dokumenty Kościoła, zwłaszcza encyklika Pawła VI Ecclesiam suam i konstytucja duszpasterska o Kościele w świecie współczesnym Gaudium et spes soboru watykańskiego II, rozumieją ową najbardziej zasadniczą postawę Kościoła wobec świata, jaką jest w ich ujęciu dialog, ze szczególnym zwróceniem uwagi na to, w jakim stosunku tak pojęty dialog pozostaje do apologii „tej nadziei, która w nas jest” (1 P 3,15), by na koniec spróbować sformułować parę wniosków wynikających dla zadań stojących dziś przed teologią fundamentalną i dotyczących jej miejsca w całości misji ewangelizacyjnej Kościoła.

\section{APOLOGIA W KOŚCIELE}

W obliczu zagrażających młodemu Kościołowi prześladowań, św. Piotr zwraca się do wiernych z następującym wskazaniem, które stało się tekstem klasycznym dla uzasadniania prawomocności apologii w Kościele:

Kyrion de ton Christon hagiasate en tais kardiais hymôn, hetoimoi aei pros apologian panti tô(i) aitounti hymas logon peri tês en hymin elpidos (1 P 3,15).

Tekst stał się klasyczny, gdyż w nim właśnie pojawia się wyraźnie słowo „apologia”. Sama jednak treść wyrażana tym pojęciem: obrona i uzasadnienie własnych przekonań, postawy, a także otrzymanej misji, występuje na kartach Nowego Testamentu często. Przede wszystkim już we wspólnej warstwie świadectwa synoptycznego o Jezusie występuje On jako broniący autentyczności 
swej misji zarówno czynem (na przykład w scenie uzdrowienia paralityka por. Mk $2,1-12$, par.), jak też słowem („Jak może szatan wyrzucać szatana?” - por. Mk 3,22 - 27). Ewangelia Janowa zaś nadaje wielu mowom Jezusa charakter obszernych apologii uwierzytelniających Jego boskie posłannictwo i wykorzystujących już te zasadnicze linie argumentacji, które staną się klasyczne w apologii Kościoła: wypełnienie w Jezusie zapowiedzi Starego Testamentu, przekonywająca wymowa czynów Jezusa: por. J 5,19 — 47; 8,12 — 59; $10,31-39$.

Podobnie uczniowie od początku bronią swego przekonania o tym, że Jezus jest Mesjaszem: por. Dz 2,14 - 36; $1 \mathrm{~J}$ 1,1 - 4; Łk 1,1 - 4,2 P 1,12-21. Typ wierzącego prowadzącego konsekwentną apologię swego przylgnięcia do Jezusa stanowi uzdrowiony niewidomy z J 9. A postołowie, zwłaszcza Paweł, przeprowadzają apologię prawomocności otrzymanego posłannictwa - por. np. Ga 1,10-2,10; to jest też najczęstszy kontekst, w jakim słowo „,apologia” pojawia się w Nowym Testamencie, poza wspomnianym wyżej fragmentem Pierwszego Listu św. Piotra ${ }^{5}$.

W świetle tych i innych świadectw biblijnych apologia własnej postawy ukazuje się więc jako istotny i niezbywalny element chrześcijańskiego świadectwa, a przynajmniej jako element apostolskiego świadectwa w początkowej fazie istnienia i działalności Kościoła.

\section{DIALOG W KOSCIELE}

Zobaczmy teraz, jak kształtuje się świadomość podstawowej funkcji dialogu w stosunkach Kościoła ze światem. Pierwsza encyklika Pawła VI, wydana w trakcie prac soboru watykańskiego II (mianowicie w 1964 r., między II a III sesją) i zaczynająca się od słów Ecclesiam suam, zawiera sugestie dotyczące głównych orientacji prac Soboru. Po rozważeniu zagadnień związanych ze samoświadomością Kościoła i jego konieczną odnową, na „trzecim miejscu — mówi papież - należy zastanowić się nad tym, jaki duch i jaka wola powinna kierować Kościołem katolickim wobec ludzi współczesnych. Powinien on mianowicie zbadać, jaki ma być jego stosunek do społeczeństwa" (ES 58) ${ }^{6}$. Otóż zasadnicza odpowiedź, jaką daje Paweł VI na tak sformułowane pytanie, zawiera się nie w słowie „apologia”, lecz w słowie „dialog”: „Kościół powinien

\footnotetext{
${ }^{5}$ Inne miejsca, w jakich występuje słowo ,apologia” w Nowym Testamencie (według: A Concordance to the Greek Testament, Edinburgh 1963): Dz 22,1; 25,16; 1 Kor 9,3; 2 Kor 7,11; Flp 1,7.16; 2 Tm 4,16. Najbliższy sensem wyrażeniu z 1 P 3,15 jest zwrot: „apologia tou Euangeliou” (Flp 1,7.16).

${ }^{6}$ Ecclesiam suam. Encyklika Jego Świq̨tobliwości Pawła VI [...] o drogach, którymi Kościót katolicki powinien kroczyć w dobie obecnej przy petnieniu swojej misji, Warszawa 1977. Dalsza numeracja rozdziałów cytowanej encykliki według tego wydania.
} 
nawiązać dialog ze społeczeństwem, w którym żyje. Dzięki temu Kościół przybiera postać słowa i orędzia” (ES 65).

Czy nie chodzi tu o jakąś całkowitą nowość nie znaną dotąd Kościołowi? W przeciwieństwie do terminu ,apologia”, słowo dialog, choć również greckiego pochodzenia, w Nowym Testamencie nie występuje, a dla oznaczenia czegoś głębszego, niż jakakolwiek zwykła rozmowa zostało wykorzystane chyba dopiero przez języki nowożytne i to stosunkowo niedawno.

O ile samo słowo jako termin teologiczny jest nowe, to treści, jakie z nim wiąże współczesne nauczanie Kościoła, tkwią głęboko w jego tradycji. Jakby uprzedzając przedstawione powyżej wątpliwości, Paweł VI, przypomina w swym dokumencie naprzód, że Sobór, którego trzecia sesja się zbliża, sam zdecydował się już wcześniej ,zwrócić swe badania i myśli ku temu szczególnemu i głównemu sposobowi postępowania Kościoła" (ES 66), a następnie przypomina, że „sposoby wypełniania obowiązku pasterskiego” przejęte przez niego po wielkich poprzednikach, poczynając od Leona XIII, przez Piusa XI i Piusa XII, a zwłaszcza Jana XXIII, wykazują znamiona zainteresowania zagadnieniami niesionymi przez nowe czasy i wysiłku, by je oświetlić wiarą chrześcijańską, stosując przy tym „nie oderwane pojęcia, lecz język właściwy ludziom naszych czasów". Ten sposób postępowania posiada, zdaniem Pawła VI, cechy dialogu i skłania jego osobiście oraz sobór do zajęcia podobnej postawy wobec świata (por. ES $67-69$ ).

„Zanim doprowadzimy świat do wiary, owszem, aby go doprowadzić do wiary, potrzeba, byśmy się do świata zbliżyli, byśmy z nim nawiązali rozmowę" (ES 68). Powyższe sformułowanie wskazuje na kontekst bliski temu, z jakim wiązało się $\mathrm{w}$ tradycyjnej teologii pojęcie apologii, z jakim związane jest ono w 1 P: na horyzoncie celów dialogu pojawia się „doprowadzenie świata do wiary". Tekst zacytowany wcześniej wskazywal, że dialog jest rozumiany jako środek nadający Kościołowi „postać słowa i orędzia”. Przyjrzymy się bliżej rozumieniu tego pojęcia przez Pawła VI:

Pod nazwą dialogu powinniśmy więc mieć przed oczyma ów prawdziwy i niewymowny rodzaj rozmowy, którą zapoczątkował i nawiązał Bóg Ojciec przez Jezusa Chrystusa w Duchu Swiętym, jeśli my, to jest Kościół, chcemy zrozumieć, jakie stosunki mamy z ludźmi nawiązać i do jakich dążyć (ES 71).

Tak rozumiany dialog nie jest już dla autora dokumentu tylko jakimś sposobem apostolskiej „taktyki” wyczytanej z postępowania bezpośrednich poprzedników na Stolicy Piotrowej, lecz urasta do rangi jednego ze znamion Kościoła, jeśli przez znamiona Kościoła rozumiemy takie jego istotne cechy, które, korzeniem sięgając misterium Trójjedynego Boga i Jego zbawczej ekonomii, przejawiają na zewnątrz, wobec świata, refleks owego misterium i uwierzytelniają przez to bosko-ludzki charakter Kościoła. Dialog jawi się w tej swo- 
istej definicji jako szczególny aspekt całego dzieła zbawienia i jako taki staje się prawzorem misji Kościoła.

Dalsze passusy tekstu rozwijają tę myśl i aplikują ją do fundamentalnej charakterystyki dialogu znamionującego Kościół. Dialog Kościoła ze światem nosi tu cechy Miłości Bożej, która z własnej, całkowicie darmowej i bezinteresownej inicjatywy zwraca się ku człowiekowi i ogarnia wszystkich ludzi, bez względu na ich dotychczasowe stanowisko czy zasługi i z pełnym poszanowaniem wolności ich odpowiedzi (por. ES 72-76). Dialog Kościoła ze światem na podobieństwo dialogu Boga $\mathrm{z}$ ludzkością ma także cechy powolnego wzrostu ze skromnych początków - jest realizacją prawa wzrostu Królestwa zawartego w przypowieści o ziarnie gorczycznym (por. ES 77).

Tak pojętą strukturę dialogu stara się nadać swemu najobszerniejszemu dokumentowi pastoralnemu sobór watykański II. We wstępie konstytucji duszpasterskiej o Kościele w świecie współczesnym Gaudium et spes ojcowie soboru, jak pamiętamy, dają najpierw wyraz głębokiej solidarności uczniów Chrystusa ze wszystkimi ludźmi współczesnymi w ,ich radości i nadziei, smutku i trwodze”, by następnie zadeklarować: „Dlatego to Sobór Watykański II, po dogłębnym rozważeniu tajemnicy Kościoła, kieruje bez wahania swe słowa już nie tylko do samych synów Kościoła i wszystkich, którzy wzywają imienia Chrystusa, ale do wszystkich ludzi" (Gaudium et spes 2).

Jest więc w zamierzeniu soboru intencja wyjścia ze słowem ku wszystkim ludziom, jest w tej intencji wola okazania w ten sposób bezinteresownej miłości przedłużającej dzieło Chrystusowe, a wyrażającej się we współpracy nad realizacją celów ludzkości:

Sobór święty wyznając najszczytniejsze powołanie człowieka [...] ofiarowuje rodzajowi ludzkiemu szczerą współpracę Kościoła dla zaprowadzenia odpowiadającego temu powołaniu braterstwa wszystkich. Kościól nie powoduje się w tym żadną ambicją ziemską, lecz zmierza ku jednemu tylko, a mianowicie, by pod kierownictwem Ducha Swiętego Pocieszyciela prowadzić dalej dzieło samego Chrystusa, który przyszedł na świat, żeby dać świadectwo prawdzie, żeby zbawiać, a nie sądzić, żeby służyć, a nie żeby Jemu służono (Gaudium et spes 3).

W zacytowanym fragmencie nie trzeba chyba podkreślać aż nadto widocznych założeń dialogu rozumianego tak, jak przedstawia go Paweł VI w Ecclesiam suam. Warto może natomiast zwrócić uwagę, że w posłudze, którą Kościół podejmuje wobec świata na przedłużeniu Chrystusowej posługi, mieści się testimonium veritatis - dawanie świadectwa prawdzie. Czy nie jesteśmy tu na tropie więzi między dialogiem a apologią rozumianą przez św. Piotra jako „zdawanie sprawy” z nadziei właściwej chrześcijanom? Spróbujmy prześledzić uważniej ten wątek. 
Wydaje się, że przy bliższym zbadaniu wypowiedzi Kościoła o apologii i dialogu widać, iż nie pozostają one do siebie nawzajem w opozycji, lecz, przynajmniej w tym znaczeniu, jakie Kościół im nadaje, wzajemnie się uzupełniają. Zwróćmy najpierw uwagę na początek Piotrowej zachęty kładącej fundament pod chrześcijański obowiązek apologii: „Kyrion de ton Christon hagiasate en tais kardiais hymôn" (1 P 3,15).

Nawiązując wyraźnie do Iz 8,13 - tekstu wskazującego Izraelitom podstawy odwagi wobec grożących nieszczęść w „święceniu” i „lękaniu się” Imienia Pana Zastępów, św. Piotr wzywa chrześcijan w obliczu nadciągających prześladowań do analogicznej postawy mężnego wytrwania przez mocne związanie z Bogiem, z tym, że „ten, który jest” objawia się i konkretyzuje w Chrystusie ${ }^{7}$ i mocniej jest podkreślony wewnętrzny charakter „święcenia” Go „w sercach”. W wezwaniu tym można wyraźnie dostrzec to samo co u Pawła VI odwołanie się, wobec konieczności zajęcia zdecydowanej i właściwej postawy wobec zewnętrznego świata, do najmocniejszego fundamentu, do misterium samego Boga objawiającego się w Chrystusie.

U Piotra, jak wiemy, ta postawa wyraża się w „obronie”, apologii, przy czym warto zwrócić uwagę na cztery aspekty formuły: „hetoimoi aei pros apologian panti tô(i) aitounti hymas logon peri tês en hymin elpidos" (1 P 3,15).

Po pi r rw sze, apologia uzależniona jest tu od pytającej postawy ze strony świata, dotyczy płaszczyzny „logosu” chrześcijańskiej egzystencji i jej odrębności; ma charakter odpowiedzi - wchodzi więc przez to w strukturę dialogu, przy czym - po w tó r e — od razu widać, że nie jest tego dialogu elementem pierwszym, lecz mającym swą rację we wcześniejszym zainteresowaniu ze strony świata, które - p o t r z e ci e - jest scharakteryzowane jako dotyczące racjonalności, czy sensu nadziei odkrywanej jako cecha wyróżniająca (poddanych próbie) chrześcijan ${ }^{8}$. Koryguje to rozpowszechnione pojęcie apologii jako „obrony wiary": nowotestamentalna ,apologia tou euaggeliou” (Flp 1,7.16) broni przede wszystkim zasadności nadziei złożonej w dobrej nowinie o zbawieniu, całego egzystencjalnego ukierunkowania człowieka otwartego ku eschatologicznemu spełnieniu. Po czwarte wreszcie gotowość zdania sprawy $\mathrm{z}$ rozumności nadziei ma wymiar powszechny; jest otwarta wobec wszystkich, ma dotyczyć każdego, kto stawia pytanie.

Jeśli przypomnimy sobie teraz znów charakterystykę dialogu w Ecclesiam suam Pawła VI, to dostrzeżemy, że apologii w ujęciu Piotra brak jednego tylko elementu owego, zakorzenionego w przylgnięciu do objawiającego się w Chry-

\footnotetext{
${ }^{7}$ Część rękopisów bizantyńskich ma zresztą (zapewne pod wplywem Izajaṡzowego podtekstu) „theon" w miejsce „christon".

${ }^{8}$ Por. charakterystykę świata pogańskiego w Ef 2,12: „choris Christou [...] elpida me echontes kai atheoi en tō kosmō".
} 
stusie Boga, wyjściu z miłością ku światu, by służyć mu powierzoną nam zbawczą prawdą: właśnie elementu podjęcia pierwszej inicjatywy. Apologia nie obejmuje całości dialogu Kościoła ze światem, ale jest jego szczególnym momentem. Wróćmy raz jeszcze do tekstu Ecclesiam suam:

„Chociaż bowiem nie ma żadnej wątpliwości - pisze papież —że skarby prawdy i łaski przekazane nam jako dziedzictwo przez ojców wiary chrześcijańskiej należy zachować w stanie nietkniętym i strzec ich zgodnie $\mathrm{z}$ napomnieniem świętego Pawła: strzeż depozytu $(1 \mathrm{Tm} 6,20)$, to jednak ani strzeżenie, ani obrona nie wyczerpują w pełni obowiązków ciążących na Kościele wobec powierzonych mu darów. Dobra bowiem przekazane Kościołowi przez Chrystusa ze swej niejako natury wymagają, by je zarazem udostęniał innym, by je rozdzielał wśród innych, ponieważ, jak dobrze wiemy, w poleceniu: Idźcie więc i nauczajcie wszystkie narody (Mt 28,19), zawarty jest najwyższy nakaz Chrystusa dany Apostołom (ES 64).

Paweł VI daje więc wyjaśnienie stosunku zachodzącego między „strzeżeniem depozytu" a misyjnym dynamizmem miłości stanowiącym „najwyższy nakaz Chrystusa”. Strzeżenie depozytu, skarbu przekazanego Kościołowi, jest konieczne dla tego, by Kościół mógł wypełnić swe ostateczne posłannictwo, jest mu podporządkowane. Zauważmy przy tym, że „strzeżenie depozytu” z 1 Tm 6,20, do którego bezpośrednio odwołuje się papież nie wyczerpuje całej treści pojęcia apologii zawartego w analizowanej zachęcie św. Piotra; można powiedzieć, że odpowiada jej pierwszemu "taktowi”: „święceniu Chrystusa” w sercu. Sama apologia zawiera jednak już coś więcej w sensie wyjścia ku rozmówcy z gotowością wyjaśnienia, zdania sprawy, uzewnętrznienia motywów zdecydowanego trwania przy Chrystusie i powierzonym przez Niego depozycie.

Dla uchwycenia całej dialektyki dialogu od punktu wyjścia do punktu docelowego może być pomocny jeszcze jeden fragment wstępu Gaudium et spes. Po wstępnej charakterystyce problemów nękających współczesny świat, ojcowie soboru piszą:

Dlatego Sobór, zaświadczając i wykładając (testificans et exponens) wiarę całego ludu Bożego, zebranego w jedno przez Chrystusa, nie potrafi wymowniej okazać swojej solidarności (coniunctionem), szacunku i miłości dla całej rodziny ludzkiej, w którą jest wszczepiony, jak nawiązując (instituendo) z nią dialog (colloquium) na temat owych różnych problemów, przynosząc światło czerpane z Ewangelii oraz dostarczając rodzajowi ludzkiemu zbawczych sił, jakie Kościól sam pod przewodnictwem Ducha Swiętego otrzymuje od swego Założyciela (Gaudium et spes 3).

Podejmując znane nam z Ecclesiam suam wątki dialogu jako formy miłości wychodzącej ku człowiekowi, tekst soborowy naświetla jaśniej sposób nawiązania owego dialogu. Sobór mianowicie pragnie wyjść od zobaczenia, uchwycenia, współprzeżycia ze współczesną ludzkością jej „radości i nadziei, jej smutków i trwóg" i zacząć rozmawiać na temat tego, co aktualnie człowieka cieszy, co boli, wzbudza nadzieję lub zatrważa, i tam przynieść naprzód refleks 
ewangelicznego światla ${ }^{9}$ oraz ową moc Ducha, którą sam żyje, a która nie może nie wzbudzać pytań o swe źródło.

W sumie więc można by próbować zrekonstruować następująco całość doświadczenia Kościoła w jego misji dialogu ze światem. Stając w obliczu świata Kościól musi naprzód odnowić swą najgłębszą życiodajną i normatywną więź jedności z ojcem przez Chrystusa w Duchu Świętym a następnie (z innego punktu widzenia trzeba by powiedzieć: „, jednocześnie”) na nowo przeżyć swą głęboką solidarność z całą rodziną ludzką, w którą jest wszczepiony i - kierowany tym samym dynamizmem miłości, dzięki któremu Ojciec posyła na świat Syna w mocy Ducha Świętego, aby służył i oddał życie na okup za wielu — rozpocząć z ludzkością dialog, szukając dla niego punktu oparcia w przeżywanych przez człowieka dramatach. Ta pierwsza faza dialogu, jeśli jest prowadzona z prawdziwie ewangeliczną miłością w całej ostrości prawdy, musi wywołać reakcję zainteresowania (czasem wręcz zaniepokojenia i sprzeciwu) i prowadzić do postawienia pytań o zasadność nadziei stojącej za chrześcijańskim świadectwem miłości i prawdy. W tym punkcie, ale w tym punkcie dopiero, w punkcie, na który trzeba umieć czekać z wielkoduszną cierpliwością, dialog przechodzi w fazę apologii nie tyle wiary, co Ewangelii - dobrej nowiny rodzącej do żywej nadziei (por. 1 P 1,3) i Kościól w pełni „przybiera postać słowa orędzia” (GS 65), które może być w różnym stopniu i w różnej formie przyjęte bądź odrzucone, co stwarza nowy punkt wyjścia dla kontynuowania procesu dialogu od punktu, który teraz stanowi dla rozmówcy „radość i nadzieję”, czy też smutek, niepokój, trwogę...

\section{ZADANIA TEOLOGII FUNDAMENTALNEJ WOBEC KOSCIELNEGO POSŁANNICTWA DIALOGU}

Naszkicowawszy w ten sposób proces dialogu prowadzonego przez Kościól ze światem, wróćmy jeszcze na koniec do zawartego w podtytule wykładu pytania o zadania, czy o posługę, jakiej może spodziewać się w tym swoim posłannictwie Kościól od dyscypliny, którą określa się dziś coraz powszechniej jako teologię fundamentalną.

Wydaje się, że „kryzys tożsamości”, jaki ta gałąź nauk kościelnych przeżyła po Soborze, przedstawiany z różnych stron choćby przez J. P. Torrella, D. Tra-

9 „Kościół idąc ku swemu własnemu zbawczemu celowi, nie tylko daje człowiekowi uczestnictwo w życiu Bożym, lecz także rozsiewa na całym świecie niejako odbite światło Boże, zwlaszcza przez to, że leczy i podnosi godność osoby ludzkiej, umacnia więź społeczeństwa ludzkiego oraz wlewa głębszy sens i znaczenie w powszednią aktywność ludzi. Dlatego też Kościół uważa, że przez poszczególnych swych członków i calą swoją społeczność może poważnie przyczynić się do tego, aby rodzina ludzka i jej historia stawały się coraz bardziej ludzkie" (Gaudium et spes 40). 
cy, R. Latourelle'a ${ }^{10}$ czy u nas M. Ruseckiego ${ }^{11}$, dotyczył właśnie tego, iż zdano sobie sprawę, że dyscyplina, która dotąd miała ambicje krytycznego opracowywania całego praktycznie istniejącego stosunku Kościoła wobec świata „Z zewnątrz", nie może sprostać takim zadaniom, jeśli Kościół, na serio, z pozycji „obronnych" chce przejść do dialogu ze światem na temat wszystkich nurtujących świat problemów. Rozumienie nadal teologii fundamentalnej jako dyscypliny dostarczającej teoretycznych podstaw dla całego tak szeroko rozumianego dialogu groziło uczynieniem $\mathrm{z}$ niej „worka bez dna” i zagubieniem jej istotnego centrum. Pozostanie przy dawnych formułach i schematach stawiało ją natomiast jakby poza głównym nurtem odnowionej relacji Kościół - świat, a nawet jakby w opozycji do niej.

Rozwiązanie trudności wydaje się leżeć w uznaniu, że, jako taka, teologia fundamentalna jest nadal „odpowiedzialna" 12 za jeden tylko, ale jakże newralgiczny, moment dialogu Kościoła ze światem: za moment apologii zawierający w sobie dwie fazy wskazane przez 1 P 3,15, za wciąż nowe uświadamianie Kościołowi jego tożsamości w jego najbardziej fundamentalnej więzi z misterium zbawienia objawionym w Chrystusie (staty element „strzeżenia depozytu”) i za wciąż nowe formułowanie odpowiedzi na pytanie o „logos” nadziei wynikającej z tej tożsamości i z tej więzi, w kontekście zmieniającego się w toku dialogu charakteru zakwestionowań (element zmienny, „,kontekstualny”, otwartej gotowości wobec każdego pytającego). Zasadniczym tematem refleksji teologii fundamentalnej pozostaje więc zawsze misterium objawienia dopełnionego w Chrystusie i przekazywanego w Kościele; istotna odnowa polega na umieszczeniu tej refleksji w szerokim horyzoncie dialogu i takie jej traktowanie, by mogła rzeczywiście dialogowi służyć.

Myślę, że takie ustawienie zadań teologii fundamentalnej zgadza się zarówno $\mathrm{z}$ podstawowymi intuicjami co do jej roli, jak i z postulatem dialogu jako podstawowej formy stosunku Kościoła do świata, a zatem zarówno z jej dotychczasową historią jak i ze sposobem jej uprawiania w ostatnich latach, to jest po wyjściu z posoborowego kryzysu tożsamości.

${ }^{10}$ Por. ich artykuly w: Problemi e prospettive di teologia fondamentale, ed. R. La to u r ell e, G. O'Collin s, Brescia 1980, s. 23 - 40,41-58, 59-84.

${ }_{11}$ M. R u s e c k i, Struktura naukowa teologii fundamentalnej, „Studia Theologica Varsaviensia” $22: 1984$ z. 1 s. $35-69$.

12 „Odpowiedzialna” w sensie współtworzenia teoretycznej i praktycznej refleksji nad poprawnością dydaktycznej prezentacji. 


\section{APOLOGIA NELL'EPOCA DEL DIALOGO}

Su alcune prospettive attuali di teologia fondamentale

\section{Riassunto}

Nell'articolo si ravvisa il contesto ecclesiale nuovo in cui si è trovata la teologia fondamentale nell'epoca in cui il rapporto fondamentale tra la Chiesa e il mondo viene definito con il concetto di „dialogo" (Paulo VI, Vaticano II...). L'autore si propone di comparare e di ravvicinare due concetti fondamentali: quell'antico di „apologia” (cf. 1 P 3,15) e quello moderno di „dialogo” — tutti e due in uso nella Chiesa per delineare il suo dovere della testimoninza ,ad extra” — e di trarne alcune conseguenze per lo stile di esporre e di sviluppare la teologia fondamentale (già „apologetica").

In seguito all'esame di alcuni brani biblici (in particolare 1 P 3,15) e dell'insegnamento della Chiesa odierna (Ecclesiam suam di Paolo VI, Gaudium et spes del Vaticano II), si propone di ravvisare l'apologia della speranza cristiana come una tappa del dialogo che la Chiesa è chiamata ad intraprendere ed a coltivare con gli uomini in ogni epoca; una tappa essenziale, che però, nello svolgersi del dialogo, non è né la prima, né l'ultima. Si potrebbe forse schematizzare cosi l'intero processo di quel dialogo, avendo davanti agli occhi una visione sintetica del dato biblico e dell'insegnamento della Chiesa:

Venendo incontro al mondo, la Chiesa deve dapprima rinnovare la sua più costitutiva e vivificante unione col Padre per il Cristo, nello Spirito Santo e poi (da un altro punto di vista si direbbe: e contemporaneamente) rivivere con intensità la sua solidarietà con l'intera famiglia umana. Retta dallo stesso dinamismo dell'amore grazie al quale il Padre manda al mondo il suo Figlio nella forza dello Spirito Santo perché serva e doni la propria vita in riscatto per tanti, essa può e deve inviare allora con l'umanità un dialogo, cercando gli spunti per esso nelle vicende e nei problemi vissuti da questa. Se quella prima tappa del dialogo viene vissuta con l'amore autenticamente evangelico e in tutta la verità, essa deve provocare delle domande (alle volte anche aggressive) sulla legittimità dela speranza che sta alla base della testimonianza cristiana di amore e di verità. A quel punto infatti, ma solo a quel punto (al quale bisogna anche saper aspettare con pazienza), il dialogo entra nella fase di apologia - non tanto della fede che del Vangelo: di quella novella buona che fà nascere l'interlocutore ad una speranza viva (cf. Gaudium et spes $\mathrm{n}^{\circ} 65$ ), il quale poi può essere accolto o rigettato dal mondo con proporzioni e intensità diverse. Si crea con ciò un nuovo punto di partenza per il dialogo che va continuato adesso alla base di quello che è diventato dell'interlocutore „la gioia e la speranza” oppure „la tristeza e la paura”.

In quel contesto ecclesiale, la teologia fondamentale sembra chiamata a servire all'insegnamento della Chiesa in quel punto del dialogo che è costituito dall'apologia - nei sue due punti complementari caratterizzati da San Pietro: far sempre presente alla Chiesa il nucleo della sua fede - la sua unione intima col mistero della salvezza in Cristo, e formulare le risposte - sempre di nuovo adeguate al contesto della cultura, al tenore delle domande — riguardanti il „logos” della sua speranza ancorata in quel mistero. Il nuovo per la teologia fondamentale è costituito dal fatto che essa deve tener conto di ravvisare cosi solo un punto dialettico nel ampio contesto delle relazioni aperte tra la Chiesa e il mondo, e che lo scopo suo è di servire ad esse. 